\title{
Die religieuse betekenis van die doop in die Gereformeerde Belydenisskrifte, veral in die Heidelbergse Kategismus
}

H Dijkstra, Groblersdal Jan $J$ van der Walt, Potchefstroom

\begin{abstract}
The religious meaning of baptism in the Reformed articles of faith, specially the Heidelberger Catechism

We have inquired after the religious meaning of the baptism in the Heidelberg Catechism. This finds expression in the personal nature of the blessing of baptism, in the trinitarian interpretation of the promise of the Gospel, it is maintained by the inextricable coherence of the promise of the Gospel and baptismal signs, baptism and faith, justification and sanctification. Finally it culminates in the baptism of infants. We come to the conclusion that the Heidelberg Catechism, within the appointed context of a personal relationship with the living God of the Covenant (I belong to my faithful Saviour, Jesus Christ, Question 1), declares and seals to us the promises of the Gospel, namely: "that not only to others, but to me also, forgiveness of sins, everlasting righteousness and blessedness, are given by God, out of pure grace, for the sake of Christ's merits alone" (Question 21).
\end{abstract}

\section{INLEIDING: DIE GEREFORMEERDE BELYDENIS HET 'N RELIGIEUSE KARAKTER}

Wanneer ons oor die religieuse betekenis van die doop in die belydenis van die kerk praat, word daarmee bedoel dat daar nie bepaald oor beskouinge wat in die belydenis vervat is, gepraat word nie, maar oor die vrese van die Here wat daarin tot uitdrukking kom (Velema, 1982:68. 78). Met ander woorde, dat ek as gelowige belyer persoonlik oor God voor God en mense uitsprake doen. Alle nadruk val op die persoonlike weerklank van die beloftes en eise, heilsversekeringe en vermanings waarmee ons Here God Homself in sy Woord openbaar, en dit in die konteks van die persoonlike ontmoeting met die lewende God. Ek word ten slotte persoonlik aangespreek en die antwoord is die uitdrukking van my persoonlike geloof soortuiging (vergelyk Tukker, 1973:7. 8. Huyser, 1963:54: Sirks, 1949:9). So gesien, het die Gereformeerde belydenisskrifte 'n duidelik aanwysbare religieuse karakter.

\section{DIE PLEK WAAR DIE DOOP IN DIE HEIDELBERGSE KATEGISMUS BELY WORD, IS RELIGIEUS GEMOTIVEERD} Ons is bewus van die samehang van die vrae en antwoorde oor die doop 
(69 - 74) met die oor die sakramente in die algemeen (65 - 68), met die oor die nagmaal $(75-80)$ en met die kerklike tug $(81-85)$. Hierdie bekende samehang moet uiteraard in berekening gebring word.

Vir bogenoemde onderwerp is die samehang van die doopvrae met die res van die Heidelbergse Kategismus (voortaan HK genoem, terwyl syfers tussen hakies na vrae en antwoorde verwys) in sy totale opset egter van nog groter belang. Die HK is analities opgebou (Weber 1968:131. 134). Die hele HK staan as ' $t$ ware in vraag en antwoord 1. Hierdie eerste vraag is nie bloot inleiding nie, maar is grondliggend aan die hele HK, in sy totale opset en na sy inhoud. Alles wat in die HK volg, lê in die paar woorde opgesluit: ek behoort aan my Verlosser Jesus Christus. Dit is die verklaringsleutel van die hele HK. En hierdie kernbelydenis is 'n eggo van die woorde uit die Ou Testament waarin die verbondsverhouding van God met sy volk telkens saamgevat word. "Ek sal hulle God wees en hulle sal my volk wees." Dit word bevestig deur die bedoeling met die HK volgens die Kerkorde van die Palts waarvan die HK deel uitgemaak het. Die onderwysing in die Christelike leer van die HK was bedoel as onderrig in die leer van die verbond, onderrig in die betekenis van die doop as teken van die verbond (vergelyk Dijkstra. 1988:192 en volgende). Die hele HK staan dus in die konteks van die verbondsverhouding tussen die Here en ons. Die woord "verbond" self, kom wel net twee maal in die HK voor, maar juis in die deel oor die sakramente: in vraag 74 oor die kinderdoop en in vraag 82 in verband met die toelating tot die nagmaal.

Binne die eie opset van die HK word die sakramente in die tweede hoofdeel oor die verlossing tussen die belydenis van die regverdiging deur die geloof as samevatting van alles wat ons glo $(59-60)$ en die derde hoofdeel oor die dankbaarheid geplaas.

Dit was die plek waar die reformatore die evangelie eksistensieel beleef het. Dit blyk reeds daaruit dat ons hier van die langste vrae en antwoorde van die HK vind. Die HK bring met hierdie plekbepaling van die doopvrae die religieuse betekenis van die doop op 'n onvergelykbare wyse tot uitdrukking. Daarmee word gesê : binne die bestaande verbondsverhouding het die doop sy spesifieke plek en funksie - nie beperk en begrens binne 'n gelsoleerde heilsorde nie, maar onbegrens op die volle terrein van daardie verbondsverhouding.

Binne hierdie verbande moet ons nou let op die religieuse betekenis van die doop soos dit saaklik bely word.

\section{DIE RELIGIEUSE BETEKENIS VAN DIE DOOP SOOS BELY IN DIE BELYDENISSKRIFTE}

In die HK word die doop gesien as "teken van die verbond" (vraag 74), waarin dit gaan om die bevestiging van die belofte van die evangelie (66, vergelyk $69,71,74)$ en die eis van 'n nuwe lewe (70).

Eweneens sien die Nederlandse Geloofsbelydenis die doop as "teken van die verbond" (artikel 34) waardeur die beloftes van ons goeie God aan 
ons beseel word (artikel 33), sodat ons van kinders van die toorn weergebore word tot kinders van God, afgesonder om heeltemal sy eiendom te wees (artikel 34). In hierdie religieuse verbondsterminologie bely ons ons doop.

\subsection{Die persoonlike aard van die heil}

Met betrekking tot die religieuse betekenis van die deel van die HK oor die doop, is die persoonlike gerigtheid van die heil die eerste wat 'n mens opval. Die enkelvoud- en meervoudsvorme in die eerste en tweede persoon wissel mekaar af. Oor die algemeen staan die begripsvrae in die eerste persoon meervoud, die "ons"'-vorm $(65,66,67,70,71,72,73)$, terwyl die oordeelsvraag, wat saamvat en persoonlik betrek, in die eerste en tweede persoon enkelvoud geformuleer is: jy - ek - my (69). Die uitsondering is vraag 74, waar uiteraard in verband met die kinderdoop van "hulle" gepraat word, maar "hulle" wat net so goed soos volwassenes in die verbond van God en in sy gemeente ingesluit is! Die religieuse verhouding word aangetoon en bely.

Met hierdie persoonlike vorme is nie in die neutrale sin van die woord, die moderne, mondige, selfstandige individu bedoel nie, maar in die religieuse sin van die woord die "ek" of "ons" wat in Christus (59), "lede van Christus" $(32,49,51,55,70,76)$, "lede van Christus en sy gemeente" (85) is. Mens sou ook kon sê dat hierdie spreekwyse van die HK verbondstaalvorme is. In die verbond gaan dit oor die belofte van die evangelie, dat die enigste offerande van Christus aan die kruis vir my gebring is (69). Dit gaan nie oor neutrale, abstrakte beloftes nie. Maar wat van deurslaggewende betekenis is, is dat hierdie persoonlike toespitsing nie individualisties vereng mag word nie. Ons moet hulle steeds in die verband van die Godsvolk, die Kerk, die Liggaam van Christus, sien staan. Die doop is dus nooit 'n blote privaat-, gesins-, of familie-aangeleentheid nie. Die hele liggaam, al sy lede is daarby betrokke.

\subsection{By die doop staan ons voor God drie-enig}

Die religieuse betekenis van die doop in die HK kom veral daarin tot uitdrukking, dat die doop trinitaries uitgelê word. In alles wat ons bely, bely ons die drie-enige God.

Ten opsigte van die algemene belydenisskrifte is dit voor-die-hand-liggend. Hulle het veral uit die ou doopsimbool ontwikkel (vergelyk Hahn, 1962; Kelly. 1960). En die ou doopsimbool wou "op een summiere wijze voor de drie-enige God zeggen: 'dit zijt Gij voor mij, dit geloof ik van U' " (Tukker, 1973:7).

Maar ook die reformatore wou niks anders bely nie (vergelyk Koopmans. 1938). Die hele reformatoriese belydenis oor die doop lé reeds opgesluit in die woorde van die Geloofsbelydenis van Nicea: ek glo in éen doop tot vergewing van sondes. Op hierdie uitdrukking, bekend uit die doopliturgie rondom die helfte van die vierde eeu (Kelly, 1960:33), loop die hele belydenis van die drie-enige God deur die dopeling uit: "Het Credo wordt uitgesproken om den Doop te erlangen. Al de woorden gaan uit naar 
eén daad: al wat de dopeling zegt en denkt heeft den doop op het oog." (Van Selms, 1948: 187.)

In die HK word die inhoud van die geloof, met name die artikels van ons algemene en ongetwyfelde Christelike geloof, aangedui as die beloftes van die evangelie (22). Dit is 'n duidelike aanwysing oor hoe weinig abstrak-rasioneel, en hoe deur en deur religieus oor die geloofswaarhede, oor die artikels van die Christelike geloof in die HK gedink word.

Van die belydenis van die drie-enige God het die opstellers van die $\mathrm{HK}$ immers geen ingewikkelde denkprobleem gemaak nie. God het Hom so in sy Woord geopenbaar (25). Dit is die evangelie, blye boodskap! En ons is persoonlik daarby betrokke: as God die Vader Hom openbaar, gaan dit oor ons skepping, as God die Seun Hom openbaar, gaan dit oor ons verlossing en as God die Heilige Gees Hom openbaar, gaan dit oor ons heiligmaking. Daarom word daar nie oor die drie-enige God deur die verstand bespiegel nie, maar is dit eenvoudig 'n kwessie van: ons "noem" die Vader, die Seun en die Heilige Gees (25). Dit is binne hierdie religieuse verbande dat die HK oor die doop handel.

In die gebruik van die sakramente gaan dit weer om hierdie belofte van die evangelie (66). God neem Self die inisiatief: Hy gee, ons ontvang - Hy het hulle self ingestel om ons die belofte van die evangelie (naamlik die vergewing van sondes en die ewige lewe vanwee die enige slagoffer van Christus aan die kruis) beter te laat verstaan en te verseel (66).

En dan kom vraag 70 en verklaar die doopbelofte (dat ons met die bloed en Gees van Christus gewas word) trinitaries(!): die Vader wat uit genade ons sondes vergewe, die Seun wat sy bloed vir ons aan die kruis vergiet en die Heilige Gees wat ons vernuwe en heilig. Vraag 74 doen dieselfde met die oog op die kinderdoop: die kinders is net so goed as die volwassenes in die verbond van God en in sy gemeente ingesluit, aan die kinders word nie minder as aan die volwassenes nie verlossing van sondes deur die bloed van Christus beloof, en aan hulle word net so goed as aan die volwassenes, die Heilige Gees beloof wat die geloof werk.

Dit is wat gebeur as ons gedoop word in die Naam van die Vader en die Seun en die Heilige Gees (71). Die doop is gevolglik nie 'n soort van selfoortuigingsplegtigheid nie. Dit geskied in die Naam van die drieenige God, van die ewig ryke God, die God van die Verbond - Hy is daarin aan die werk! Die begrippe "pand" en "waartekens" (73) bevestig dat God in sy trou deur hulle werk. As die Vader en die Seun en die Heilige Gees sluit Hy my, in terme van sy werke volgens die HK, van alle kante in. Hy neem die inisiatief en gee dit binne die verbondsverhouding nooit uit sy hande nie. Wanneer daar in verband met die doop gedwaal word, lê die wortels ten diepste in die grond van 'n verkeerde trinitariese interpretasie.

Hierdie trinitariese geleding in die belydenis van die doop kan ook in die Nederlandse Geloofsbelydenis aangewys word, by name in artikel 33 (God . . . die Heilige Gees . . . Jesus Christus) en in artikel 34 (Jesus 
Christus . . God ons genadige Vader . . Christus . . . die Heilige Gees). In artikel 34 word die trinitariese doopformule ook uitdruklik aangehaal. Die Nederlandse Geloofsbelydenis laat ook die volle nadruk daarop val dat God drie-enig in die doop aan die werk is. Sy soewereine beskikking sit agter die doop, en dit sluit tegelyk ons heil in: Christus is die waarheid van die doop en die Heilige Gees die krag daarvan (vergelyk Polman, IV. s.j. : 152-153, 160).

Die religieuse betekenis van die doop word verder deur die HK onderstreep wanneer bely word dat die doop ons die belofte van die evangelie beter laat verstaan en verseël.

\subsection{Die doop verseël die belofte van die evangelie}

Neuser het daarop gewys dat die beloftebegrip hier in die HK sterk op die voorgrond tree $(66,67,69,70,71,73,74)$. Hy kom tot die konklusie: "Die Taufe ist im Heidelberger Katechismus durchgehend Zuspruch des Evangeliums und Versiegelung dieser Verheissung durch das Zeichen." (Neuser, 1967: 12.) Die verkondiging van die evangelie word deur die doop beteken en verseël. Hier is dit vir die onderwerp onder bespreking in die eerste plek van belang dat die aanduiding: "verkondiging van die heilige evangelie" (65) en verder: "die beloftes van die evangelie" (66) daarop dui, dat die HK fokus op die boodskap van die Bybel en op die inhoud daarvan (vergelyk Coenen, 1963: 85-86: Hesse, 1936:471-472). Die Skrif funksioneer hier in die verbondsverhouding tussen die drie-enige Verbondsgod en ons. Die sentrale inhoud van die Skrifte is evangelie (19), blye boodskap van herstel van die verbondsverhouding. Daarom praat die HK graag van beloftes $(71,77)$, beloftes van die Woord (117) en beloftes van die evangelie $(22,66)$. Dit is verbondstaal! Daarom is die evangelie uiteraard daarop aangewys om verkondig te word $(65,66,67$, 83). Daarom is die evangelie net soos die Naam van God, die Kerk, die sakramente, ensovoorts heilig $(19,65,83,84)$. Die evangelie is van 'n ander orde, dit is van bo, dit is van die Here! Maar dit is vir ons, mense, bedoel.

Die belofte van die evangelie lui: vergewing van sondes en die ewige lewe (66). Daar is net hierdie éen en dieselfde belofte van die evangelie; die woord of die prediking en die sakramentsbelofte is dieselfde (67). Hierdie belofte van die evangelie lui as doopbelofte: dat ek met die bloed en Gees van Christus gewas is (69)

Mens moet egter duidelik onderskei: dit is nie die waterdoop as sodanig wat op 'n magiese wyse die vergewing van sondes en die ewige lewe beter laat verstaan en verseel nie. Nee, 'n mens mag die tekens nie isoleer en oorskat, soos by Rome nie. Die teken het nie 'n eie bestaan of funksie los van die Woord nie (Weber, 1962:657), maar die belofte van die evangelie word in die doop bekragtig. Die Woord of die verkondiging van die evangelie of die belofte van die evangelie en teken van die doop is saam sakrament van die vergewing van sondes en die ewige lewe.

Tereg sê Neuser met verwysing na vraag 66 en 69: "Alles, was die sakramentalen Zeichen sind, sind sie durch ihrem Bezug auf das Wort" en verder: "Die Wirkungen des Wortes und des Zeichens erfolgen also mehr 
in einem Miteinander als in einem Nacheinander." (Neuser, 1967:20, 22.) Hierdie verbinding van die verkondiging van die evangelie wat in die doop beteken en verseel word, loop dwarsdeur die vrae en antwoorde van die HK oor die sakramente. Op grond daarvan is van die doop in die HK as 'n "Verkündigungshandlung" gepraat (Neuser, 1967:12). Daardeur word eensydighede vermy en die goddelike inisiatief gehandhaaf. So word aan die eenkant 'n verobjektivering van die doop in 'n opusoperatum-denke en aan die ander kant 'n versubjektivering in 'n spiritualistiese vervlugtiging, waarby die teken ontledig en die doop tot 'n simboliese handeling gedevalueer word, vermy.

Hierby moet die volle betekenis en die religieuse werklikheidsgehalte van die belofte-begrip egter steeds gehonoreer word. Dit kan alleen geskied as die hegte samehang tussen Woord en Gees $(31,54,65,123)$ juis hier by die sakramente erken word. Dan sal die teken-begrip teen verselfstandiging, veruiterliking en ontlediging beskerm word. Die ware teken-begrip bevestig juis dat die sakrament op die Woord wys en die evangelie beseel en bekragtig (vergelyk ook Polman, Il s.j.:241).

Ook in die Nederlandse Geloofbelydenis artikel 33 bely ons dat ons goeie God die sakramente by die Woord van die evangelie gevoeg het om vir ons uitwendige sintuie des te beter voor oe te stel wat Hy ons deur sy Woord te kenne gee, en in artikel 34 word bely dat ons die genadegawes nie deur die uitwendige water nie, maar wel deur die besprenkeling met die kosbare bloed van die Seun van God deur die Heilige Gees ontvang. Die hegte samehang en fyn aanvoeling word bewaar, sodat die religieuse gehalte van die doop nie aangetas word nie.

Die religieuse betekenis van die doop kom verder daarin tot uitdrukking dat ons hoe langer hoe meer die sondes afsterwe en in 'n godsalige en onberispelike lewe wandel.

\subsection{Doop is gerig op lewensheiliging}

Juis as teken en seel van die verbond gaan dit in die doop nie net oor die beloftes van die evangelie nie, maar omdat daar in alle verbonde twee dele is, ook oor die eis van die verbond. Die verkondiging van die evangelie, die beloftes van die evangelie, wil geloof by ons werk en versterk $(21,84)$ en wil ons nuut maak en heilig $(70)$. Die lewende saad van die Woord is ' $n$ werksame $k r a g$ (Rom $1: 16 ; 1$ Kor $1: 18 ; 1$ Tess $2: 13$ ).

Die geloof by die ontvanger van die doop word in die HK nie as voorwaarde vir die doop gestel nie. In vergelyking met die Klein Kategismus van Ursinus is die afwesigheid daarvan in die HK opvallend en wil dit voorkom asof enige sinspeling in daardie rigting, selfs tot in die algemene sakramentsleer, geskrap is $(66,69,73,74)$.

Wat die prediking betref, word die geloof daardeur gewerk. As die belofte van die doop is dat ons met die bloed en Gees van Christus gewas word, dan is doop ook 'n vorm van prediking. Augustinus het reeds tussen die hoorbare en sigbare Woord onderskei. In beide gevalle vereis die blye boodskap nie geloof as voorwaarde nie, maar is dit gerig op die geloof. Dit gaan in prediking en doop oor een en dieselfde belofte (66 - 
67 en $69-71)$. Alleen die funksie verskil: die prediking werk en versterk geloof terwyl die doop dit versterk. Die prediking werk deur die Woord, terwyl die doop deur Woord en teken werk. Verkondiging en verseëling kan deur 'n langer tyd van mekaar geskei wees, dan kan die geloof gewek wees voordat die belofte van die doop bekragtig word in die "volwassedoop". Maar as verkondiging en verseëling direk op mekaar volg of een is, dan het ons "kinderdoop". Maar die geloof volg in beide gevalle op die beloftewoord wat lewe uit die dood gebied.

Geloof en doop hoort dus bymekaar, maar nie as oorsaak of voorwaarde en gevolg nie, omdat ons "den Glauben ebenso allein im Empfangen haben, wie wir die Taufe empfangen" (Weber II, 1962:659) - geloof en doop het dieselfde struktuur! (Vergelyk Berkouwer, 1954:139-140.)

Ook wanneer verder gevra word na die verhouding van belofte en gebod, regverdiging en heiliging by die doop, moet gewaarsku word teen 'n soort van polêre spanningsverhouding van 'n abstrakte, van mekaar geisoleerde belofte en gebod (vergelyk Berkouwer, 1954:207; Dijkstra, 1988:201). Dit gaan oor belofte en gebod binne die verbondsverhouding, binne die religieuse konteks van: ek behoort aan die Here Jesus Christus en dárom, deur die Heilige Gees verseker, van harte gewillig en bereid gemaak om verder vir Hom te lewe (1). Vergiffenis van sondes is ten diepste 'n werksame krag.

Die doopbelofte dat ons met die bloed en Gees van Christus gewas is, hou beide sondevergewing en vernuwing, regverdiging en heiliging in. Dit word respektiewelik aan Christus en aan die Heilige Gees toegeskryf (70; vergelyk 86 en 115). Wanneer die uitdrukking "bloed en Gees" in vraag 69,72 en 73 slegs op sondevergewing betrek word, moet ons waarskynlik aan 'n inklusiewe spreekwyse van die doopbelofte dink en word die nie-polêre verhouding van regverdiging en heiliging in die $\mathrm{HK}$ ook daardeur juis onderstreep. Die vernuwing is reeds by die sondevergewing ingesluit. So word die wedergeboorte in vraag 73 ook as deel van die sondevergewing gesien.

As vraag 70 vergewing en vernuwing in die doop onderskei, is met vergewing die omvattende nuwe verhouding met God aangedui, wat deur God gewerk en aan ons belowe word. Die beloftewoord is egter regverdigende Woord (ter wille van die bloed van Christus wat Hy in sy offerande aan die kruis vir ons vergiet het) en heiligende Woord (om deur die Heilige Gees vernuut en geheilig te wees tot lede van Christus, sodat ons hoe langer hoe meer die sondes afsterwe en in 'n godsalige, onberispelike lewe wandel). Met die belofte van sondevergewing, die ewige lewe en die vernuwing staan 'n mens aan die begin: die gedoopte kind moet die belofte aanvaar, in die geloof groei, hoe langer hoe meer (vergelyk $115,123)$ die sonde afsterwe en in 'n godsalige, onberispelike lewe wandel. Op grond van die ryke toesegging stel die HK die onmoontlikheid dat iemand wat in Christus ingeplant is, geen vrugte van dankbaarheid sou voortbring nie (64; vergelyk 86). Omdat jy eiendom van Christus is, verbondskind is, staan jy volledig onder die heerskappyaansprake van die Here God. Dit is nie die druk van 'n gehoorsaamheidscis wat 
van buite af op jou druk nie, maar op grond van die verbondsbelofte dat die Here die wet op die tafel van jou hart sal skryf is dit die geboorte en groei van 'n "nuwe gehoorsaamheid".

Die religieuse verband waarbinne die HK oor die doop praat, onderstreep dat die doop nie net teken en seël van die belofte van die evangelie in die beperkte sin van die woord is nie, maar ook teken en seel van die eis en verpligting wat die evangelie inhou, - al is dit so dat laasgenoemde element hier in die HK nie telkens uitdruklik die nadruk gekry het wat ons sou verwag het nie. Die rede daarvoor was waarskynlik om met die Lutherane tot ' $n$ vergelyk te kon kom (vergelyk Hesse, 1936:475-476). Tog word hierdie element uitdruklik genoem in samehang met die belofte in vraag 70 , en in breer verband van die HK in die nagmaalsleer $(76,77,81)$ en veral in die vrae oor die sleutels van die hemelryk, in direkte aansluiting met die deel oor die sakramente: om te waak dat die verbond van God nie ontheilig en sy toorn oor die gemeente opgewek word nie (82).

Die Nederlandse Geloofsbelydenis stel die genadegawes wat nie deur die uitwendige water nie. maar die bloed van Christus deur die Heilige Gees bewerkstellig word, ook in onlosmaaklike samehang as reiniging van sondes én wedergeboorte van kinders van die toorn tot kinders van God; gesuiwer en gereinig van alle vuilheid en ongeregtigheid én vernuwing van die hart; ontklee word van die oue mens en al sy werke en beklee word met die nuwe mens (artikel 34).

\subsection{Die jong kinders net so goed as die volwassenes betrokke}

Vraag 74 oor die kinderdoop is die toets vir en hoogtepunt van die onderwysing in die Christelike leer van die doop in die HK. Hier staan of val die waaragtigheid van die belofte van die evangelie en verseëling van hierdie belofte deur die teken, waarop die HK so klem gelê het.

Die redes waarom die jong kindertjies gedoop moet word, word daarom as 't ware opgestapel.

(a) Die kinders is in die verbond en in die gemeente van God ingesluit. Uit die enkele plekke in die HK waar uitdruklik oor die verbond gehandel word, kan ons aflei dat dit daar nie bloot oor 'n voorlopige en voorwaardelike aanbod van genade gaan nie, maar oor 'n verbintenis van God met sy volk waarin Hy hulle vergewing van sondes en vernuwing deur die Gees toesê en hulle van hulle kant verplig tot 'n lewe van geloof en bekering. Hierby is die kinders ingesluit. Alle mense word lid van die Kerk van die Here deur uitverkiesing, deur vergaderings-, beskermingsen onderhoudingswerk van die Seun van God (54).

Met die grootste stelligheid en bewoenheid bely ons van die gelowiges se kindertjies, dat ons hulle behoort te doop en met die teken van die verbond moet beseel omdat Christus sy bloed nie minder vir hulle as vir ons vergiet het nie (Nederlandse Gelcofsbelydenis. artikel 34).

Die doop word aan hulle bedien op grond van die feit dat God met sy volk 'n verbond gesluit het, en die krag van sy goddelike beloftes toegesé 
het (vergelyk Berkouwer, 1954:225). Die doop as teken en seel van die verbond is teken en seel van God se verbondsgenáde. Dit is die eerste fundamentele grond van die kinderdoop. Dit is die eén en al vir tyd en ewigheid, ook vir my kind: ek behoort aan die Here (1), ek is heeltemal sy eiendom (Nederlandse Geloofsbelydenis, artikel 34).

(b) Die kinders deel in die beloftes van verlossing van die sondes en die gawe van die Gees wat die geloof werk. Die belofte staan vas en word toegesê, ook aan die kinders.

$\mathrm{Na}$ aanleiding van die versigtige formulering, dat die Heilige Gees, wat die geloof werk, belowe word, haal Neuser (1967:30) vir O. Weber (1962: 676) aan: "Es ist vom neutestamentlichen Verständnis der Taufe her moglich, dass der Taufvorgang und der individuelle, bewusste Glaube zeitlich-empirisch nicht zusammenfallen. Daher ist auch Kindertaufe moglich." En Berkouwer wys daarop dat Calvyn wel sterk nadruk op die korrelasie tussen geloof en sakrament lê, maar geen behoefte het om hierdie korrelasievraagstuk te kristalliseer in die moment van die doop nie (aangehaal deur Polman, IV s.j.:213).

Ook by die doop van die kinders bly die eis van die verbond gehandhaaf Die Gees is die eerste gawe, en die Gees lei die kind juis op hierdie pad van adellike plig.

Die grond van die doop is egter nie die geloof nie, maar die soendood van Christus. En die versoening kan ons net ontvang. In die doop gaan dit nie oor ons selfoortuigingskrag nie, maar oor wat ons Here buite ons om aan die kruis vir ons gedoen het. Die grond vir die doop kan dus nooit iets anders as God se genade in Jesus Christus wees nie - ook nie as volwassenes gedoop word nie. Daarom is alle doop ten diepste kinderdoop (Althaus, aangehaal deur Weber, II 1962:677).

(c) As teken van die verbond is die doop ' $n$ inlywings- en onderskeidingsteken.

Inlywing en opname in die volk van God geskied deur uitverkiesing en vergewing van sondes (54 en 56 in Sondag 21 oor die kerk!).

Deur die doop word die verbondskinders van die kinders van die ongelowiges onderskei of afgesonder. In die Nederlandse Geloofsbelydenis word ook uitdruklik van die doop gesê: deur die doop word ons in die kerk van God opgeneem en van alle ongelowiges en vreemde godsdienste afgesonder, om heeltemal sy eiendom te wees en sy merkteken en vaandel te dra (artikel 34). Ook die Goeie Herder merk die lammers van sy kudde! (Koopmans, 1949:173.)

Diegene wat hulle as ongelowige en goddelose mense gedra, ontheilig die verbond van God (82) en as hulle nie van hul skandelike lewe afstand doen nie, word die sakramente hulle verbied (85). 'n Ongelowige (83), 'n ongelowige en goddelose (82), 'n ongelowige en huigelaar (84) en hul kinders is dus van die sakramente, ook van die doop uitgesluit. Van hulle word die verbondskinders, dit wil sè kinders van verbondsouers, deur die doop as teken van die verbond onderskei (74). 
Die afleiding dat doop in die kring van die verbond aan kinders van gelowige ouers bedien word, hou nie in dat die geloof (van die ouers) nou tog voorwaarde en grond vir die doop sou word nie. Dat die doop as verseeling van die goddelike belofte op die agtergrond geskuif sou word en plek sou inruim vir 'n soort natuurlike teologie (Neuser, 1967:33), berus op valse teëstellings. Gelowige ouers wat geheel en al die eiendom van Christus is en in wie se lewe Christus en sy Woord regeer, het immers ' $n$ heerlike roeping en taak om hul kinders wat die merkteken van "kind van die Here" dra, in die leer van die verbond, in die belofte en eis van die verbond, te onderrig. En die grond daarvoor is tog niks anders as die beloftes en toesegginge van die evangelie nie. Daar is geen sterker motivering vir die opvoeding in die vrese en die tug van die Here, as juis die realiteit van die belofte van die evangelie nie. Rus die imperatief en volle paranese dan nie op die vaste grond van die indikatief van die liefde van God in Jesus Christus nie?

Die Dordtse Leerreêls verwys uitdruklik na die kinders van die gelowige ouers of godsalige ouers (I, 17; vergelyk ook NGB 34) en verklaar van hulle dat hulle nie van nature heilig is nie. Hulle is inteendeel "verdorwe kinders", met 'n "verdorwe natuur". "in sonde ontvang en as kinders van die toorn gebore, onbekwaam tot enige saligmakende goeie werk, geneig tot die kwaad, dood in die sonde en slawe van die sonde" (HI/IV, 2 en 3). Maar kragtens die genadeverbond waarin hulle met hul ouers opgeneem is, is hulle geheilig tot sy eiendom. Aan hulle is die beloftes van die verbond toegesê. Daaruit maak die Dordtse Leerreêls die troosvolle gevolgtrekking, dat ouers nooit moet twyfel aan die uitverkiesing en saligheid van hul kinders wat vroeg sterf nie.

Hier word nie geredeneer of gespekuleer nie, maar godvrugtigbewoe nagesê wat God se Woord voorsê. God is getrou aan sy Woord en die beloftes van sy Woord.

(d) Ten slotte: die doop kom in die plek van die besnydenis. Hierdie argument kan nie afgemaak word deur te sê dat dit waaroor dit in die besnydenis gegaan het met die koms van die Messias afgehandel is nie (Barth, 1953:31). Barth beweer: "Taufe und Beschneidung sind beides Bundeszeichen - mehr lässt sich nicht sagen." (Neuser. 1967:33: vergelyk Barth. 1948:96.)

In die Pauliniese briewe wys die besnydenis bo homself uit. Met die koms en werk van Christus kry dit 'n diepe sin juis in die doop (Kol $2: 11$ -

12): (vergelyk Versteeg, 1983:105-106)! Dit gaan in die parallel van besnydenis en doop nie bloot oor klakkelose navolging van ' $n$ bepaalde verouderde verbondsteologie nie (Neuser. 1967:33), maar oor die kontinuiteit tussen die Ou en Nuwe Verbond ten opsigte van die geestelike genadekarakter van die verbond (vergelyk Kakes, 1953:103; Koopmans, 1949:173). Getrou aan die Gereformeerde tradisie speel hierdie parallel in die literatuur oor die kinderdoop 'n geweldige rol.

Ook in die Nederlandse Geloofsbelydenis, artikel 34 speel die argument van die doop wat in die plek van die besnydenis gekom het ' $n$ belangrike rol 


\section{SAMEVATTING}

Die onderwerp van die doop bly steeds van die grootste belang. Hier word die opvattings oor die verhouding van God en wëreld, skepping en herskepping, goddelike en menslike natuur van Christus, sonde en genade, gees en stof telkens eietyds prakties tot uitdrukking gebring (vergelyk H. Bavinck, aangehaal deur Polman, II s.j. : 229-230). Ons eie opvattings oor die religieuse grondpatroon van die verhouding tussen die Here en ons en ons en die Here, ons "overtuiging van de weg des heils" (Polman, II, s.j.:252), tree hier duidelik aan die dag.

Daar is gepoog om in enkele bree trekke die religieuse karakter en betekenis van die doop in die $\mathrm{HK}$, met verwysing na die ander belydenisskrifte, aan te wys.

Daar is in die eerste plek gelet op die religieuse gehalte van die persoonlike aard van die heil in die HK.

Vervolgens is gevra na die religieuse betekenis van die trinitariese interpretasie van die doopbelofte - hoe die ewig ryke God ons van alle kante in sy trou insluit.

Daarna het ons gesien hoe hierdie religieuse geheimenis bewaar is in die onlosmaaklike samehang van beloftewoord en teken, in die verhouding van doop en geloof, regverdiging en heiliging, belofte en eis.

Ten slotte is die religieuse betekenis van die doop in die HK juis in die vraag na die kinderdoop getoets en het dit sy toppunt bereik.

Daar word tot die gevolgtrekking gekom dat die HK nie in die vorm van abstrakte en neutrale leerstellings oor die doop handel nie, maar binne die aangewese konteks van Sondag 1 (ek behoort aan die Here), voor die aangesig van die troue Verbondsgod persoonlik getuig van die heerlike volheid van die beloftes van die evangelie, wat in die doop beseel en bekragtig word: "dat nie alleen aan ander nie, maar ook aan my vergewing van sondes, ewige geregtigheid en saligheid deur God geskenk is uit loutere genade alleen ter wille van die verdienste van Christus" (21).

Op hierdie wyse word die beloftes van die evangelie net een maal in my doop beseel en bekragtig. Ek kan 'n lewe lank daarop terugval. Fk kan altyd weer in diepe dankbaarheid en verwondering tot die enigste Bron terugkeer om rus en nuwe krag te vind by die God van my doop - in sy ewige verkiesing, in sy troubeloftes, in sy heilige barmhartigheid . . . Hy is "langer dan de tijd, breder dan de wereld, dieper dan het hart en hoger dan de hemel". (KJ Popma, aangehaal deur Besselaar, s.j : 205.)

Voor God se aangesig tref die verwondering myself die gevoeligste: "nie alleen aan ander nie, maar ook aan my!" Binne hierdie religieuse konteks is die ander nie die probleem nie, minste van almal die kindertjies. Vir hulle geld die versekering: "net so goed as die volwassenes!"

\section{BIBLIOGRAFIE}

Bakhuizen van den Brink, JN. 1940. De Nederlandsche belijdenisschriften, Vergelijkende teksten. Amsterdam: Holland 
Barth, K. 1948. Die christeliche Lehre nach dem Heidelberger Katechismus. Zurich: Zollikon.

1953. 4. Aufl. Die kirchliche Lehre von der Taufe. Zurich: Zollikon.

Berkouwer, GC. 1954. De sacramenten. Dogmatische studien. Kampen: Kok.

Besselaar, AT, s.j. Artikel 33. Instelling en functie van de sacramenten; en: Artikel 34. De heilige doop. (In Delleman, Th, red. Altijd bereid tot verantwoording. Kort commentaar op de Nederlandse Geloofsbelijdenis. Aalten: De Graafschap, p 193-207.)

Coenen, L. 1963. Wort Gottes und Heiliger Geist. (In Coenen, L, Hrsg. Handbuch zum Heidelberger Katechismus. Neukirchen: Neukirchener Verlag p 81-90.)

Cullmann, O. 1943. Die ersten christlichen Glaubensbekenntnisse. Zurich: Zollikon.

Dijkstra, H. 1980. Die aard van die persoonlike toespitsing van die heil in die Heidelberg. se Kategismus ('n steekproef). In die Skriflig, 14(56) : 40-53, Des.

1988. Die betekenis van die Heidelbergse Kategismus as leerboek vir die verbondsonderrig van die kerkjeug. (In Venter, CJH, red. God bou op deur sy Woord. Huldigingsbundel Jan $\mathrm{J}$ van der Walt met sy vyf en sestigste verjaarsdag. Potchefstroom: PU vir CHO. p 190-208.)

Floor, L. 1983. Die heilige doop in die Nuwe Testament. Potchefstroom: Teologiese Publikasies.

Hahn. A \& Hahn, GL. (1897) 1962. 3. Aufl. Bibliothek der Symbole und Glaubensregeln der alten Kirche. Hildesheim: Olms.

Gereformeerde Kerke Suid-Afrika Handelinge 43e Nasionale Sinode. (Potchefstroom) 1988.

Hartvelt, GP. 1962, Petrus Boquinus. Gereformeerd theologisch tijdschrift, 62(3):4977 s.j. Tastbaar evangelie. Nieuwe commentaar Heidelbergse Catechismus III Aalten: De Graafschap.

Hesse, H. 1936. Zur Sakramentslehre des Heidelberger Katechismus nach den Fragen 65-68. (Theologische Aufsatze. Karl Barth zum 50. Geburtstag. Munchen: Kaiser. p 467-489.)

Huijser, PhJ. 1963. Catechismus en Christelijke religie. Opdracht en dienst, 37(4) :5456 , Jan.

Jacobs. P. 1959. Theologie reformierter Bekenntnisschriften in Grundzugen. Neukirchen: Neukirchener Verlag.

Kakes, H. 1953. De doop in de Nederlandse belijdenisgeschriften. Kampen: Kok.

Kelly, JND. 1960. Early Christian creeds. London: Longmans.

Koop, E. 1985. De Dordtse Leerregels dichterbij gebracht. Kampen: Van den Berg

Koopmans, J. 1938. Het oudkerkelijk dogma in de reformatie, bepaaldelijk bij Calvijn (Proefskrif ThD - Utrecht. Wageningen: Veenman.)

1949: De Nederlandse Geloofsbelijdenis. Amsterdam: Holland

Lang, A. Hrsg. (1907) 1967. Der Heidelberger Katechismus und vier verwandte Katechismen (Leo Juds und Microns kleine Katechismen sowie die zwei Vorarbeiten Ursins.) Darmstadt: Wissenschaftliche Buchgesellschaft.

Marcel, PCh. 1963. Die Lehre von der Kirche und den Sakramenten. (In Coenen, L, Hrsg. Handbuch zum Heidelberger Katechismus. Neukirchen: Neukirchener Verlag. p 135-158.)

Neuser. WH. 1967. Die Tauflehre des Heidelberger Katechismus. Theologische Existenz heute. Neue Folge nr 139. Munchen: Kaiser.

Pery. A 1963. Der Heidelberger Katechismus. Erlauterungen zu seinen 129 Fragen und Antworten. Neukirchen: Neukirchener Verlag.

Polman. ADR. s.j. (1953). Onze Nederlandsche Geloofsbelijdenis, Verklaard uit het verleden. geconfronteerd met het heden. IV Franeker: Wever.

s.j. (195-). Woord en belijdenis. Eenvoudige verklaring van de Nederlandsche Geloof sbelijdenis. II Franeker: Wever.

Popma. SP. s.j. Artikel 1. De ene en enige God (In Delleman, Th: red. Altijd bereid tot verantwoording. Kort commentaar op de Nederlandse Geloofsbelijdenis Aalten: De Graafschap. p 16-21.)

Sirks, GJ. 1949. Voor God wil ik belijden. Amsterdam: Ploegsma. 
Tukker, WL. 1973. Ten geleide. (In Goedhart. H, red. De religie van het belijden. Kampen: Kok. p 7-8.)

Van Selms, A. 1948. Licht uit Licht. Het christelijk geloof naar de belijdenis van Nicea. Amsterdam: Ploegsma.

Velema. JH. 1982. De actualiteit van onze belijdenisschriften nu. Ambtelijk contact, 21(6) : 62-80. Jun.

Versteeg. JP. 1983. De doop volgens het Nieuwe Testament. (Van 't Spijker, W et al. Rondom de doopvont. Kampen: Goudriaan. p 9-133.)

Weber, 0. 1962. Grundlagen der Dogmatik II. Neukirchen: Neukirchener Verlag. 1968. Analytische theologie. Zum geschichtlichen Standort des Heidelberger Katechismus. (In Weber, O. Die Treue Gottes in der Geschichte der Kirche. Gesammelte Aufsatze II. Neukirchen: Neukirchener Verlag. p 131-146.) 